\title{
A new method for the determination of plutonium and americium using high pressure microwave digestion and alpha-spectrometry or ICP-SMS
}

\author{
Fabienne Luisier · José Antonio Corcho Alvarado · \\ Philipp Steinmann • Michael Krachler • \\ Pascal Froidevaux
}

Received: 11 March 2009/Published online: 17 June 2009

(C) Akadémiai Kiadó, Budapest, Hungary 2009

\begin{abstract}
Plutonium and americium are radionuclides particularly difficult to measure in environmental samples because they are $\alpha$-emitters and therefore necessitate a careful separation before any measurement, either using radiometric methods or ICP-SMS. Recent developments in extraction chromatography resins such as Eichrom ${ }^{\circledR}$ TRU and TEVA have resolved many of the analytical problems but drawbacks such as low recovery and spectral interferences still occasionally occur. Here, we report on the use of the new Eichrom ${ }^{\circledR}$ DGA resin in association with TEVA resin and high pressure microwave acid leaching for the sequential determination of plutonium and americium in environmental samples. The method results in average recoveries of $83 \pm 15 \%$ for plutonium and $73 \pm 22 \%$ for americium $(n=60)$, and a less than $10 \%$ deviation from reference values of four IAEA reference materials and three samples from intercomparisons exercises. The method is also suitable for measuring ${ }^{239} \mathrm{Pu}$ in water samples at the $\mu \mathrm{Bq} / \mathrm{l}$ level, if ICP-SMS is used for the measurement.
\end{abstract}

F. Luisier · J. A. Corcho Alvarado · P. Froidevaux ( $)$ University Institute of Radiation Physics, University Hospital Center, University of Lausanne, Grand Pré 1, 1007 Lausanne, Switzerland

e-mail: pascal.froidevaux@chuv.ch

\section{P. Steinmann}

Consumer Protection, Radiation Protection, Swiss Federal Office of Public Health, Bern, Switzerland

M. Krachler

Institute of Geosciences, University of Heidelberg, Heidelberg, Germany
Keywords Plutonium · Americium ·

Microwaves digestion - TEVA resin - DGA resin . ICP-SMS

\section{Introduction}

Plutonium $(\mathrm{Pu})$ is an anthropogenic actinide produced by neutron capture reactions of ${ }^{238} \mathrm{U} .{ }^{241}$ Americium $\left({ }^{241} \mathrm{Am}\right)$ is the daughter product of the $\beta$-decay of ${ }^{241} \mathrm{Pu}$. Nuclear testing between 1955 and 1963 released a significant amount of these radionuclides, mainly in the Northern hemisphere [1]. At the local and regional level, accidents in nuclear facilities have also released significant quantities of these radioisotopes. Considering the high radio-toxicity of $\mathrm{Pu}$ and $\mathrm{Am}$, accurate methods are required to measure their activities in the environment and to evaluate the dose to the public.

$\mathrm{Pu}$ and Am are commonly measured using $\alpha$-spectrometry [2-4], which necessitates a complex preparation of the source before measurement in semi-conductor detectors. Besides, environmental samples often contain other $\alpha$-emitter radionuclides ( $\mathrm{U}$, Th and their daughters products), at much higher activities than $\mathrm{Pu}$ and $\mathrm{Am}$. Thus, radiochemical separation is used to avoid spectral interferences by other isotopes. Moreover, since the activities of $\mathrm{Pu}$ and $\mathrm{Am}$ remain at a low level (e.g., $<5 \mathrm{~Bq} / \mathrm{kg}$ for the ${ }^{239 / 240} \mathrm{Pu}$ in soil samples), large samples are needed to reach the required detection limit [5]. This means that elaborate chemical separation and purification steps are needed to measure ${ }^{241} \mathrm{Am}$ and $\mathrm{Pu}$ using alpha-spectrometry. In recent years, with the development of mass spectrometry techniques (ICP-MS), researchers have also been able to measure $\mathrm{Pu}$ radioisotopes by their masses [6-8]. However, a chemical separation is still needed in order to 
eliminate potential interferences, such as mass isobaric interferences $\left({ }^{238} \mathrm{U}\right.$ on $\left.{ }^{238} \mathrm{Pu}\right)$, polyatomic interferences $\left({ }^{207} \mathrm{PbNOH}_{2}\right.$ on $\left.{ }^{239} \mathrm{Pu}\right)$ or hydride interferences $\left({ }^{238} \mathrm{UH}\right.$ on $\left.{ }^{239} \mathrm{Pu}\right)$.

Most of the radiochemical protocols follow three main steps: sample digestion, chemical separation, and source preparation before the measurement. For the sample digestion, acid leaching and borate fusion are often used [9, 10], but are time-consuming [4] and moreover, borate fusion cannot be conducted on large samples (e.g., $>5 \mathrm{~g}$ ). Microwave digestion is another option for the dissolution of the sample matrix, that is faster and uses less reagents, but refractory oxides of plutonium might not be carried out into solution [4, 7]. More recently, high pressure microwave digestion systems (e.g. UltraClave, Milestone Inc. Shelton, CT) have also become available for the digestion of environmental and biological samples. This type of apparatus combines microwave heating with high-pressure vessel technology, making it possible to conduct batch reactions at pressures and temperatures up to 200 bar and $200{ }^{\circ} \mathrm{C}$, respectively, thus allowing the dissolution of many refractory compounds.

After the digestion step, the interferences are usually eliminated in several precipitation and extraction steps. For several decades, liquid-liquid extraction and ion exchange chromatography were the best approaches [2, 11]. Although these methods are still used [10, 12, 13], most of the recent methodologies are based on extraction chromatography resins using Eichrom ${ }^{\circledR}$ TEVA for Pu and TRU for Am [14-16]. Using these extraction chromatographic resins considerably reduces the time and reagent volumes required for the analysis [17]. TEVA and TRU resins have been used successfully in a large number of research works $[16,18]$. However, using the TRU resin has sometimes led to low recoveries of Am in samples with high iron content [18]. This is mainly due to the high sensitivity of the resin to the content of trivalent iron.

More recently, a new extraction chromatographic resin $\left(\right.$ DGA, Eichrom $^{\circledR}$ ) showing a high uptake for trivalent lanthanides and actinides was developed [19]. This new resin has been tested in a few studies for the extraction of Am. High recoveries have been reported even in complex sample matrices with an elevated content of Fe(III) [20, $21]$.

In this paper, we present a new procedure for the determination of $\mathrm{Pu}$ and $\mathrm{Am}$ in environmental samples $(<0.1 \mathrm{mBq} / \mathrm{kg})$, based on the latest developments in extraction chromatography and sample digestion. The procedure combines the use of high pressure microwave digestion for the sample wet digestion, with the extraction chromatographic resins (TEVA and DGA). In order to concentrate the actinides in a small volume, an iron hydroxide precipitation was performed before the separation step. This precipitation is an important step and is not a limitation for the separation, because both resins are not highly sensitive to the iron content in contrast to the TRU resin. Thus, large water samples could be analyzed after an iron hydroxide precipitation. The method was tested with several reference materials and with samples from two inter-comparison runs. It was then applied to measure ${ }^{239} \mathrm{Pu}$ at the picogram level in soil water samples using ICP-SMS. Our method was also used for the determination of $\mathrm{Pu}$ and $\mathrm{Am}$ using $\alpha$-spectrometry in large samples such as $20 \mathrm{~g}$ of ashed soil or $200 \mathrm{~L}$ of water and ${ }^{239} \mathrm{Pu}$ by ICP-SMS in water (up to $5 \mathrm{~L}$ ).

\section{Experimental}

\section{Reagents}

If not otherwise stated, all reagents were of analytical grade (Fluka, Buchs, Switzerland). Pre-packed columns of $2 \mathrm{~mL}$ of TEVA and DGA resins were supplied by Triskem International (Bruz, France). Small TEVA columns were prepared in the lab by filling $1 \mathrm{~mL}$ pipette tips plugged with glasswool with $100 \mathrm{mg}$ of resin. Radiochemical isotope tracers $\left({ }^{242} \mathrm{Pu}\right.$ and $\left.{ }^{243} \mathrm{Am}\right)$ used for the determination of the experimental recovery were traceable to NIST standards (NIST, Ionizing Radiation Division).

\section{Quality control}

Soils and sediments reference materials (IAEA-SOIL-6, IAEA-368, IAEA-367, and IAEA-300) were used to test the procedure. The procedure was further tested in two international inter-comparisons, the first one organized by the BfS (Bundesamt für Strahlenschutz, BfS 2/2008) for water samples [22], and the second one organized by PROCORAD for fecal ashes samples [23]. The validation in water samples was conducted with a reference solution of ${ }^{239} \mathrm{Pu}$ from a PROCORAD inter-comparison [24]. Aliquots of $100 \mu \mathrm{L}$ of the ${ }^{239} \mathrm{Pu}$ reference solution were diluted to 1-5 L with ultra-pure water. In the case of the BfS 2/2008 intercomparison runs, aliquots of the water samples were diluted to $3 \mathrm{~L}$ with ultra-pure water $(0.05 \mu \mathrm{S})$ in order to be in the same range of activities as soil water samples.

\section{Environmental water samples}

Soil water samples were collected in alpine soils (Piora, Switzerland) at 5, 10, and $15 \mathrm{~cm}$ depth using suction cups with nylon membranes having a pore size of $0.45 \mu \mathrm{m}$. After sampling, the water samples were acidified with $2 \mathrm{~mL} / \mathrm{L}$ of $65 \% \mathrm{HNO}_{3}$ to avoid losses through microbial 
activity and adsorption on the vessel walls. Large volumes of water $(200 \mathrm{~L})$, from small streams in the proximity of the soil water sample site, were pumped and filtrated through $0.45 \mu \mathrm{m}$.

\section{Radiochemical procedures}

\section{Sample preparation and dissolution}

One to thirty grams of ashes from soils or sediments, depending on the activity of the sample, were spiked with known amounts of ${ }^{242} \mathrm{Pu}$ and ${ }^{243} \mathrm{Am}$ (ca. $50 \mathrm{mBq}$ ) and mixed with $50 \mathrm{~mL}$ of $8 \mathrm{M} \mathrm{HNO}_{3}$ and $3 \mathrm{~mL}$ of $30 \% \mathrm{H}_{2} \mathrm{O}_{2}$. The samples were digested in a microwave UltraClave system (Milestone Inc., Shelton, CT). The following steps were applied: (1) $\mathrm{T}_{\max }=170{ }^{\circ} \mathrm{C}$ and $\mathrm{P}_{\max }=120$ bars, $900 \mathrm{~W}, \mathrm{t}=20 \mathrm{~min}$, (2) $\mathrm{T}_{\max }=170{ }^{\circ} \mathrm{C}, \mathrm{P}_{\max }=150$ bars, $500 \mathrm{~W}, \mathrm{t}=20 \mathrm{~min}$, and (3) cooling. The samples were then centrifuged $(3,000 \mathrm{rtm}, 20 \mathrm{mn})$ and filtered (Schleicher \& Schuell 589/2). The residue was discarded. The filtrate was diluted to $500 \mathrm{~mL}$, and the oxidation state of $\mathrm{Pu}$ was adjusted to $(3+)$ with $1 \mathrm{~g}$ of hydroxylamine and $1 \mathrm{~g}$ of ascorbic acid. Interferences such as alkaline cations or iron were then eliminated through an alkaline-earth oxalate precipitation at $\mathrm{pH} 1.5-2$ with $15 \mathrm{~g}$ of oxalic acid and the $\mathrm{pH}$ was adjusted by adding $30 \% \mathrm{NH}_{4} \mathrm{OH}$. After decantation and centrifugation, the precipitate was wet-ashed in $25 \mathrm{~mL}$ $65 \% \mathrm{HNO}_{3}$ using the following microwave UltraClave program: (1) $\mathrm{T}_{\max }=150{ }^{\circ} \mathrm{C}$ and $\mathrm{P}_{\max }=120$ bars, $900 \mathrm{~W}$, $\mathrm{t}=10 \min$, (2) $\mathrm{T}_{\max }=170{ }^{\circ} \mathrm{C}, \mathrm{P}_{\max }=150$ bars, $700 \mathrm{~W}$, $\mathrm{t}=10 \mathrm{~min}$, and (3) cooling. After the microwave step, the solution was diluted to $400 \mathrm{~mL}$. The solution was then ready for the actinides separation. Fecal ashes were treated in the same manner as soil and sediment samples.

Soil waters typically contain $5-15 \mathrm{mg} / \mathrm{L}$ of dissolved or colloidal organic carbon. This organic matter was oxidized by adding $200 \mathrm{mg}$ of $\mathrm{KMnO}_{4}$ to $3-5 \mathrm{~L}$ of the sample overnight. If the solutions were still purple after one night of mixing (presence of $\mathrm{KMnO}_{4}$ ), a few drops of $\mathrm{NH}_{2} \mathrm{OH} \cdot \mathrm{HCl}$ solution $(25 \mathrm{~g} / \mathrm{L})$ were added until the coloration disappeared. Tracers of ${ }^{242} \mathrm{Pu}$ and ${ }^{243} \mathrm{Am}$ (11 mBq) were then added. The solutions were then ready for the actinides pre-concentration. The water samples for the quality control were acidified ( $2 \mathrm{~mL} / \mathrm{L}$ of $65 \%) \mathrm{HNO}_{3}$ and treated as soil water samples.

Large volume samples (200 L) of stream water were spiked with ${ }^{234} \mathrm{Am}$ and ${ }^{242} \mathrm{Pu}(50 \mathrm{mBq}$ each). Then $\mathrm{Pu}$ and Am were co-precipitated on iron hydroxides. After decantation, the iron hydroxide precipitate was re-dissolved in $50 \mathrm{~mL}$ of $32 \% \mathrm{HCl}$ and the volume was adjusted to $400 \mathrm{~mL}$ with water. Oxalate precipitation was then carried out in the same manner as for the soil samples.
Actinides separation

The actinides were concentrated in an iron hydroxides precipitate as follows: 100-200 mg of $\mathrm{FeCl}_{3} \cdot 6 \mathrm{H}_{2} \mathrm{O}$ was added to all samples and iron hydroxides were precipitated at pH 6 using 30\% $\mathrm{NH}_{4} \mathrm{OH}$. After decantation and centrifugation, the precipitate was dissolved in $8 \mathrm{M} \mathrm{HNO}_{3}$. The oxidation state of $\mathrm{Pu}$ was adjusted to (IV) by adding $20 \mathrm{mg}$ of $\mathrm{NaNO}_{2}$ and heating at $70{ }^{\circ} \mathrm{C}$ for $10 \mathrm{~min}$.

A TEVA cartridge $(2 \mathrm{~mL})$ was clipped on top of a DGA cartridge $(2 \mathrm{~mL})$, and then stacked on a vacuum box (Supelco ${ }^{\circledR}$ VISIPREP). The resins were conditioned with $10 \mathrm{~mL}$ of $\mathrm{HNO}_{3} 8 \mathrm{M}$. The sample solution was then loaded onto the cartridge at a rate of $1 \mathrm{~mL} / \mathrm{min}$. Beakers and columns were washed with $2 \times 5 \mathrm{~mL}$ of $8 \mathrm{M} \mathrm{HNO}_{3}$. After this step, the cartridges were separated. Finally, $\mathrm{Pu}$ was stripped from the TEVA cartridge with $15 \mathrm{~mL}$ of $9 \mathrm{M} \mathrm{HCl} /$ $0.1 \mathrm{M} \mathrm{HI}$. The Pu fraction was evaporated to dryness, and the iodide was oxidized by evaporating three times with $1 \mathrm{~mL}$ of $65 \% \mathrm{HNO}_{3}$. The final residue was re-dissolved with $2 \mathrm{~mL}$ of $8 \mathrm{M} \mathrm{HNO}_{3}$. This solution was then loaded onto a small column of $100 \mathrm{mg}$ of TEVA resin for further purification of the $\mathrm{Pu}$ fraction. The micro-column was washed with $2 \mathrm{~mL}$ of $8 \mathrm{M} \mathrm{HNO}_{3}$ and $3 \mathrm{~mL}$ of $9 \mathrm{M} \mathrm{HCl}$. Then, the Pu was eluted with $2 \mathrm{~mL}$ of $9 \mathrm{M} \mathrm{HCl} / 0.1 \mathrm{M} \mathrm{HI}$, evaporated to dryness and iodide residue oxidized with drops of $65 \% \mathrm{HNO}_{3}$.

For alpha spectrometry measurements, $\mathrm{Pu}$ was electrodeposited in a sulfate buffer $(\mathrm{pH}=1.9)$ at $1.2 \mathrm{~A}$ for $75 \mathrm{~min}$ according to the procedure described by Bajo et al. [25]. For ICP-SMS measurement, the evaporate was dissolved in $1 \mathrm{~mL}$ of $3 \% \mathrm{HNO}_{3}$ Ultrapure $^{\circledR}$. In the case of ICP-SMS, the purification of the TEVA $100 \mathrm{mg}$ microcolumn was carried out using Ultrapure ${ }^{\circledR}$ reagents to minimize the $U$ contamination.

Am was extracted from the DGA column with $15 \mathrm{~mL}$ $0.5 \mathrm{M} \mathrm{HCl} / 0.03 \mathrm{M} \mathrm{NaNO}_{2}$ and the solution was evaporated to dryness. The residue was dissolved in $5 \mathrm{~mL}$ of $2 \mathrm{M}$ $\mathrm{NH}_{4} \mathrm{SCN}$ in $0.1 \mathrm{M} \mathrm{HCOOH}$. The solution was loaded onto a TEVA cartridge $(2 \mathrm{~mL})$, previously conditioned with $5 \mathrm{~mL}$ of $2 \mathrm{M} \mathrm{NH}_{4} \mathrm{SCN}$. The column was washed with $5 \mathrm{~mL}$ of $2 \mathrm{M} \mathrm{NH}_{4} \mathrm{SCN}$ and $10 \mathrm{~mL}$ of $1 \mathrm{M} \mathrm{NH}_{4} \mathrm{SCN}$ to remove any lanthanide cations. Finally, Am was eluted with $15 \mathrm{~mL}$ of $2 \mathrm{M} \mathrm{HCl}$ and the remains of $\mathrm{NH}_{4} \mathrm{SCN}$ were destroyed with $8-10 \mathrm{~mL}$ of $\mathrm{HNO}_{3}: \mathrm{HCl}$ (1:3) under heating. The solution was then evaporated to dryness and re-dissolved in $1 \mathrm{~mL}$ of $65 \% \mathrm{HNO}_{3}$. Am was electro-deposited with the same protocol described in Bajo et al. [25].

\section{Instrumental analyses}

Alpha spectrometry: alpha spectrometry measurements were carried out using an Alpha Analyst spectrometer 
(Canberra Electronique, Savagny-le-Temple, France). The detector is an ion implanted planar silicon (PIPS) with an active area of $450 \mathrm{~mm}^{2}$ and a warranted resolution of $18 \mathrm{keV}$. Sources were measured for $10^{6} \mathrm{~s}$ and the spectra were analyzed with GENIE 2000 for $\alpha$-spectrometry. The distance from the source to the detector assures an efficiency of $24 \pm 1 \%$ (Fig. 1).

ICP-SMS: All ICP-MS measurements were carried out using a single collector ICP sector field mass spectrometer (ICP-SMS, Element2, Thermo Fisher Scientific, Bremen, Germany) operated under clean room conditions and equipped with a guard electrode to eliminate secondary discharge in the plasma and to enhance overall sensitivity.
The micro volume autosampler (SC-2, Elemental Scientific Inc, Omaha, NE) transported the liquid samples $(\sim 1 \mathrm{~mL})$ to a high efficiency sample introduction system (Apex IR, Elemental Scientific Inc.) consisting of a heated spray chamber and a Peltier cooled condenser. Before entering the plasma of the ICP, the dried sample aerosol was passed through a second spray chamber for further stabilization to obtain a smooth ICP-SMS signal. Data were acquired in the low resolution mode of the ICP-SMS at $\mathrm{m} / \mathrm{z} 238,239,240$, 241 , and 242 similar to the procedure described by Zheng et al. [26]. For the calculation of the ${ }^{238} \mathrm{UH}^{+}$formation rate that interferes with the reliable quantification of ${ }^{239} \mathrm{Pu}$, a $100 \mathrm{pg} / \mathrm{g}$ U solution was monitored regularly.
Fig. 1 Chemical separation scheme of the new method for measuring plutonium and americium in environmental samples after the acid leaching, the oxalate precipitation, and iron precipitation steps

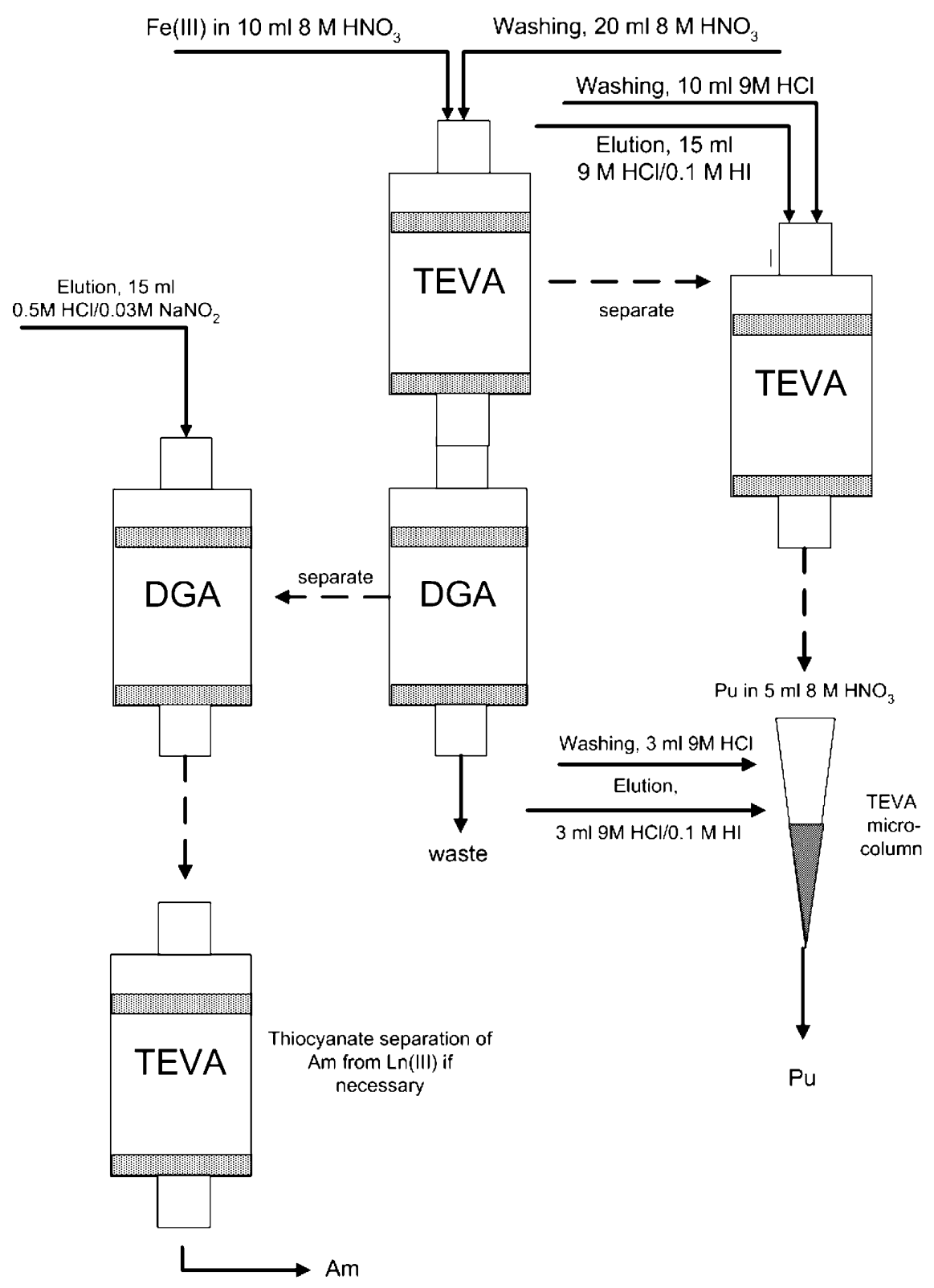




\section{Results}

Figure 2 presents analysis results of plutonium and americium in the IAEA reference materials (soils and sediments) and in the PROCORAD 2008 intercomparison samples (fecal ashes [23]). The overall recoveries are displayed in Table 1. The Fig. 2 compares the reference values reported for the samples with the results obtained using both our former and new methods. The former method combined the use of the AG1 $\times 8$ exchange resin with the Eichrom TRU extraction chromatographic resin and was in use in our laboratory until 2007 [27]. The results show that there are no significant differences between the values determined with both methods and the reference values. The activity levels of the IAEA certified samples and PROCORAD 2008 intercomparison exercise cover a large interval of values, from 1 to $39 \mathrm{~Bq} / \mathrm{kg}$ for plutonium and from 0.4 to $2 \mathrm{~Bq} / \mathrm{kg}$ for ${ }^{241} \mathrm{Am}$. In this respect, they enable a validation of the method in a range of activities that are often encountered in the environment. For instance, the activities in soils and sediments in Switzerland are often
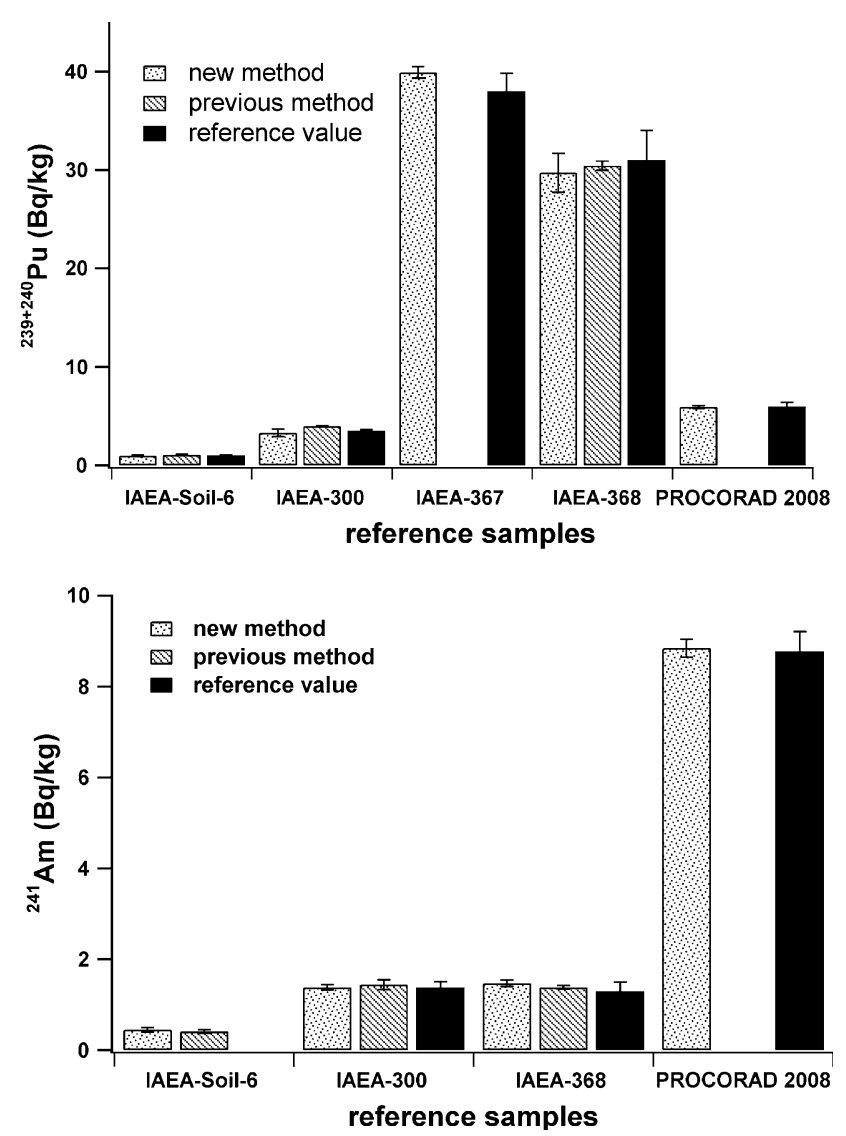

Fig. 2 Results of ${ }^{239+240} \mathrm{Pu}$ and ${ }^{241} \mathrm{Am}$ measurement using the new method, compared to the previous method and reference values for different IAEA reference samples and PROCORAD 2008 fecal ash sample
Table 1 Average recoveries of ${ }^{242} \mathrm{Pu}$ and ${ }^{243} \mathrm{Am}$ for the samples used in the quality control of the new method

\begin{tabular}{lllll}
\hline Samples & $\begin{array}{l}\text { Number } \\
\text { of analyses }\end{array}$ & $\begin{array}{l}{ }^{242} \mathrm{Pu} \\
\text { recovery }\end{array}$ & $\begin{array}{l}\text { Number of } \\
\text { analyses }\end{array}$ & $\begin{array}{l}{ }^{243} \mathrm{Am} \\
\text { recovery }\end{array}$ \\
\hline IAEA-soil-6 & 6 & 88 & 6 & 62 \\
IAEA-367 & 1 & 73 & 2 & 82 \\
IAEA-368 & 4 & 79 & 3 & 79 \\
IAEA-300 & 1 & 79 & 1 & 40 \\
PROCORAD 2008 & 3 & 92 & 3 & 60 \\
BfS 2/2008 & 3 & 74 & 6 & 83 \\
\hline
\end{tabular}

between 0.2 and $3 \mathrm{~Bq} / \mathrm{kg}$ but the soil of mountainous areas can have activities as high as $30 \mathrm{~Bq} / \mathrm{kg}$.

The proposed method was used for the determination of $\mathrm{Pu}$ and $\mathrm{Am}$ in about $2.5 \mathrm{~g}$ of fecal ashes samples, in the framework of the PROCORAD 2008 intercomparison exercise. The results deviated from the target values by less than $2.5 \%$ for americium and less than $5 \%$ for plutonium, confirming that the method can also be used for radiotoxicological analyses.

Table 1 presents the details of the measurements that were carried out during the validation of the radiochemical procedure. The recoveries were more than $70 \%$ for plutonium and more than $60 \%$ for americium. For the IAEA reference materials, the Am activity values are only indicative because there are no certified values for this radioisotope. This is mainly due to the fact that ${ }^{241} \mathrm{Am}$ is the daughter product of ${ }^{241} \mathrm{Pu}$, which has a short half-life of 14.4 years, and therefore the ${ }^{241} \mathrm{Am}$ activity in the sample will evolve with time.

In the IAEA-soil-6, we measured an average activity of ${ }^{241} \mathrm{Am}$ of $0.41 \pm 0.03 \quad(\mathrm{n}=6)$. For this sample, the ${ }^{239+240} \mathrm{Pu}$ reference value is $1.04 \pm 0.08$. The IAEA-soil-6 was sampled in Austria in 1983, before the Chernobyl accident. In this respect the ${ }^{241} \mathrm{Am} /{ }^{239+240} \mathrm{Pu}$ ratio should be similar to the one found in Western Europe for global bomb testing fallout, e.g., 0.4 (value in 2008 in Switzerland). Here, we found a ratio of $0.39 \pm 0.03$, which is very close to the expected value for global fallout. This result validate our method for measuring ${ }^{241} \mathrm{Am}$ in soil samples.

The soil sample IAEA-375 was also analyzed $(n=5)$ even if there are no reference values for plutonium and americium but only information values. The average recoveries were $79 \pm 5 \%$ for plutonium and $83 \pm 12 \%$ for americium. We found an activity range for plutonium between 0.32 and $0.48 \mathrm{~Bq} / \mathrm{kg}$, which is slightly higher than the interval of $0.26-0.34 \mathrm{~Bq} / \mathrm{kg}$ reported by IAEA. However, we found significantly higher activities for ${ }^{241} \mathrm{Am}$ $(0.31-0.61 \mathrm{~Bq} / \mathrm{kg})$, compared to the range of $(0.11-$ $0.15 \mathrm{~Bq} / \mathrm{kg}$ ) given by the IAEA. This result probably indicates the presence of significant levels of ${ }^{241} \mathrm{Pu}$ in this sample. 
In 2008, we applied the method presented in this article to 28 soils, 10 sediments, 3 mosses, 4 large volume air filters $\left(>350,000 \mathrm{~m}^{3}\right), 9$ large water samples $(100-200 \mathrm{~L})$, 5 carbonates deposits $(>10 \mathrm{~g})$ and 3 fecal ashes samples (ca. $2.5 \mathrm{~g}$ ). For the soils and sediments, the quantities involved in the separation scheme amounted to $20 \mathrm{~g}$ of ashes. The average recoveries were $82 \pm 15 \%$ for plutonium, and $73 \pm 22 \%$ for americium; which were higher than the recoveries obtained with our former method. The former method (AG1 $\times 8$ and TRU resins, hydroxylamine elution of plutonium) resulted in average recoveries of $57 \pm 16 \%$ for plutonium $(\mathrm{n}=240), \quad$ and $\quad 66 \pm 22$ ( $\mathrm{n}=196$ ) for americium.

Nevertheless, not only good recovery and a small deviation from reference values are needed to validate a method for radionuclides determination. In alpha spectrometry, poor separation factors may lead to peak interferences such as ${ }^{243} \mathrm{Am}$ for ${ }^{239 / 240} \mathrm{Pu}$ and ${ }^{210} \mathrm{Po}$ for ${ }^{243} \mathrm{Am}$ tracer. Also, uranium can interfere with the ${ }^{242} \mathrm{Pu}$ tracer peak while ${ }^{228} \mathrm{Th}$ will hinder measuring ${ }^{238} \mathrm{Pu}$. As shown in Fig. 3, the spectra of plutonium and americium obtained with the proposed method do not show interferences from other $\alpha$-emitter radionuclides, even if some of the potential interferences are present in large activities in soils and sediments samples (e.g., uranium series and thorium series). Moreover, if a significant mass of stable elements (e.g. $\mathrm{Fe}^{3+}$ or $\left.\mathrm{Ln}^{3+}\right)$ or any residue of organic matter are still
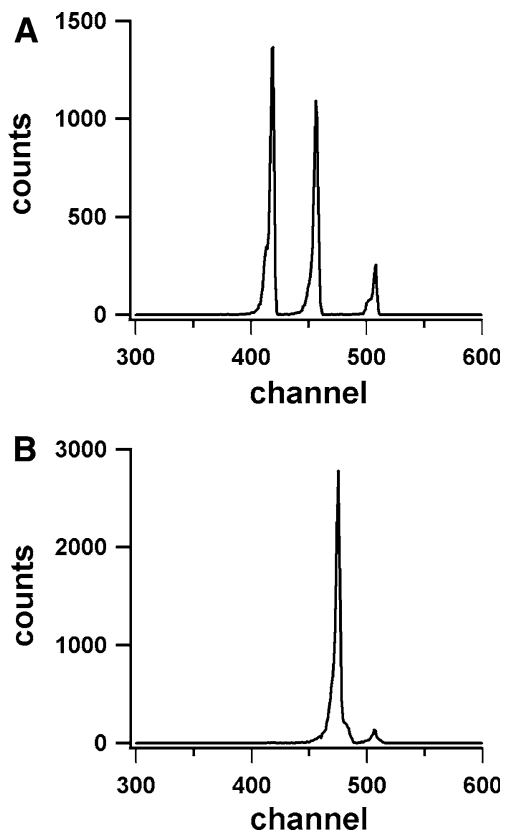

Fig. $3 \alpha$-spectra of (a) ${ }^{239+240} \mathrm{Pu}$ (peak at channel number 456 ) and ${ }^{238} \mathrm{Pu}$ (channel number 508) measurement in a soil sample with ${ }^{242} \mathrm{Pu}$ (channel number 419) as tracer and (b) ${ }^{241}$ Am (channel number 506) in the same sample with ${ }^{243} \mathrm{Am}$ (channel number 475 ) as tracer. Activities are 30 and $1.5 \mathrm{~Bq} / \mathrm{kg}$ for $\mathrm{Pu}$ and $\mathrm{Am}$, respectively. Counting time is $10^{6} \mathrm{~s}$ present during the electrodeposition process, it will reduce the resolution of the peaks, leading to larger peaks than expected. In our work, the resolution of the peaks, given by the Full Width Half Maximum (FWHM), is between 25 and $37 \mathrm{keV}$ for a counting efficiency of $24 \pm 1 \%$, which is somewhat better compared to other published methodologies [21].

The new method was adapted to the determination of plutonium and americium in water and soil solution samples. The quality control of the method was carried out on a ${ }^{239} \mathrm{Pu}$ reference solution, and in water samples from one intercomparison exercises (2008 [22]). The results of the quality control are presented in Table 2, in which the results of the analysis of ${ }^{239} \mathrm{Pu}$ in soil water samples by ICP-SMS are also given. Deviations are all less than $10 \%$ with respect to the target values. ${ }^{239} \mathrm{Pu}$ has also been satisfactorily quantified at the $\mu \mathrm{Bq} / \mathrm{l}$ by ICP-SMS, even if ${ }^{238} \mathrm{U}-\mathrm{H}$ still constitutes an interference that must be taken into account at such a low level of activity (see "Discussion").

\section{Discussion}

The method that we propose here provides high recoveries even for large and difficult samples such as $20 \mathrm{~g}$ of soils and sediments ashes. The validation resulted in a deviation of less than $5 \%$ from the reference value, either using $\alpha$-spectrometry or ICP-SMS. Overall chemical yields are well within the range of values published in other studies. [7, 10, 21] Nevertheless, our method shows several advantages over existing procedures.

First, the use of the high pressure microwave digestion system, in which 6 samples can be simultaneously wet digested, considerably reduces both analytical time and work as well as the amount of reagents used. For instance, large amounts of samples up to $30 \mathrm{~g}$ of ashes can be acid leached in $50 \mathrm{~mL}$ of $8 \mathrm{M} \mathrm{HNO}_{3}$. Reproducibility of the digestion step is assured by the program control over the temperature, pressure and reaction time. The total time for digestion is less than $90 \mathrm{~min}$, including the final cooling step. Another advantage is that, as microwave leaching occurs in a closed receptacle, there is no risk of splashing and cross-contamination. Furthermore, as alkaline-earth oxalate precipitation at low $\mathrm{pH}$ (ca. 1.5) is a standard method for actinides pre-concentration, the wet ashing of the precipitate can be carried out in $20 \mathrm{~mL}$ of $65 \% \mathrm{HNO}_{3}$ in only $40 \mathrm{~min}$, cooling time included.

Second, using DGA resin permits a second pre-concentration step of the actinides with an iron hydroxides precipitate using $50 \mathrm{mg}$ of $\mathrm{Fe}^{3+}$. Indeed the tolerance of the DGA resin to iron during the americium extraction step allows for a more versatile preparation of the loading 
Table 2 Results obtained for soil water samples and surface water (Piora) and quality control samples by using the method proposed in this article combined with $\alpha$-spectrometry or ICP-SMS

\begin{tabular}{|c|c|c|c|c|c|c|}
\hline Radionuclide & Sample & $\begin{array}{l}\text { Number of } \\
\text { analysis }\end{array}$ & $\begin{array}{l}\text { Activity } \\
(\mathrm{mBq} / \mathrm{l})\end{array}$ & $\begin{array}{l}\text { Target value } \\
(\mathrm{mBq} / \mathrm{l})\end{array}$ & $\begin{array}{l}95 \% \text { confidence } \\
\text { interval }(\mathrm{mBq} / \mathrm{l})\end{array}$ & $\begin{array}{l}\text { Type of } \\
\text { measurement }\end{array}$ \\
\hline \multirow[t]{7}{*}{${ }^{239+240} \mathrm{Pu}^{\mathrm{a}}$} & PROCORAD 2001 & 3 & $3.06 \pm 0.12$ & 2.87 & $2.61-3.24$ & ICP-SMS \\
\hline & Piora $1 \mathrm{~m} 10$ & 1 & $0.046 \pm 0.012$ & & & ICP-SMS \\
\hline & Piora $2 \mathrm{w} 10$ & 1 & $0.018 \pm 0.001$ & & & ICP-SMS \\
\hline & Piora $8 \mathrm{p} 10$ & 1 & $0.050 \pm 0.004$ & & & ICP-SMS \\
\hline & Piora 8p (200 L) & 1 & $0.008 \pm 0.001$ & & & $\alpha$-Spectrometry \\
\hline & BfS 2/2008 Reales Wasser & 3 & $455 \pm 20$ & 394 & $291-497$ & $\alpha$-Spectrometry \\
\hline & BfS 2/2008 Modellwasser & 3 & $640 \pm 30$ & 712 & $492-932$ & $\alpha$-Spectrometry \\
\hline \multirow[t]{2}{*}{${ }^{241} \mathrm{Am}$} & BfS 2/2008 Reales Wasser & 3 & $346 \pm 15$ & 324 & $261-387$ & $\alpha$-Spectrometry \\
\hline & BfS 2/2008 Modellwasser & 3 & $501 \pm 15$ & 474 & $350-590$ & $\alpha$-Spectrometry \\
\hline
\end{tabular}

Analytical quality was controlled through two intercomparison exercises and one certified ${ }^{239} \mathrm{Pu}$ reference solution

a When ICP-SMS is used, only ${ }^{239} \mathrm{Pu}$ is indicated

solution, which is the opposite of the TRU resin. In our case, the dissolution of iron hydroxides precipitate in less than $20 \mathrm{~mL}$ of $8 \mathrm{M} \mathrm{HNO}_{3}$ reduces the elution time and the volume of reagents. However, we observed that even a small amount of iron, if present during the electrodeposition step, leads to considerably lower americium recoveries. In order to avoid this effect, a quantitative elimination of the iron from the DGA resin is required before the americium elution. Thus a careful washing of the DGA cartridge with $8 \mathrm{M} \mathrm{HNO}_{3}$ until the yellowish coloration of the cartridge disappears must be carried out before stripping of americium. After the elution of americium from the DGA resin, we used a further purification step using a TEVA cartridge in order to eliminate the lanthanides that will hamper the electrodeposition step, if present in the solution. This step can be removed in the separation of matrices which do not contain significant amount of lanthanides (e.g., urines and water).

A third advantage of the method resides in stripping plutonium from the TEVA resin with a mixture of $9 \mathrm{M} \mathrm{HCl}$ / $0.1 \mathrm{M}$ HI. The iodide reduces the $\mathrm{Pu}(\mathrm{IV})$ to $\mathrm{Pu}(\mathrm{III})$, which does not form an anionic complex with chloride and so is then easily stripped from the resin. Other potential interfering elements such as U(VI) and Po(IV) are retained on the TEVA column as anionic chloride complexes. Clean spectra, free of interferences, are typically obtained using this method (Fig. 3). This is an important advantage over the former method which occasionally resulted in contamination of the $\alpha$-spectra. This contamination could come from the hydroxylamine solution's ( $25 \mathrm{~g} / \mathrm{L}$ ) lower selectivity to strip plutonium from the AG1 $\times 8$ columns $(12 \mathrm{~mL})$.

ICP-MS has become a valuable alternative to $\alpha$-spectrometry for measuring ${ }^{239} \mathrm{Pu}$ and ${ }^{240} \mathrm{Pu}$. This method has lower detection limits for ${ }^{239} \mathrm{Pu}$ than $\alpha$-spectrometry; nevertheless it suffers from some important drawbacks compared to $\alpha$-spectrometry. One of the main problems regarding the ICP-MS method is the very low specific activity of ${ }^{238} \mathrm{U}$ that renders ICP-MS much more sensitive to ${ }^{238} \mathrm{U}$ interference compared to $\alpha$-spectrometry. In fact, ${ }^{238} \mathrm{U}$ can form the polyatomic interference ${ }^{238} \mathrm{UH}^{+}$species which will appear in the ${ }^{239} \mathrm{Pu}$ window in the ICP-MS spectrum. Thus, when ICP-MS is involved in the determination of ultra-low levels of ${ }^{239} \mathrm{Pu}$, the maximum tolerable concentration of uranium is on the order of a few ppt [8]. This means that the separation scheme is more critical and laborious when using ICP-MS compared to $\alpha$-spectrometry. Often, additional separations by extraction chromatography are required to reach an acceptable purity. Applying this approach, we were able to determine using ICP-SMS the ${ }^{239} \mathrm{Pu}$ content in soil solutions from a sub-alpine area. In the worst case, we were required to withdraw $14 \mathrm{cps}$ of ${ }^{238} \mathrm{UH}^{+}$ in the spectral window of ${ }^{239} \mathrm{Pu}$ that was counting $30 \mathrm{cps}$. This relatively large contribution of ${ }^{238} \mathrm{UH}^{+}$to the ${ }^{239} \mathrm{Pu}$ signal requires a stable and robust instrumental performance to obtain reliable and accurate results. The results reported here clearly demonstrate that the analytical procedure applied provide these features yielding high quality data.

\section{Conclusions}

The analytical procedure presented in this paper was used in our environmental radioactivity survey and quality control program in 2008 and gave very reliable results in term of overall recovery, $\alpha$-spectrum and ICP-SMS spectrum interferences and bias to the reference values.

Moreover, the use of pressurized microwave acid leaching and wet ashing of oxalate precipitate permits a 
rapid, efficient and clean dissolution of the sample and destruction of oxalate within a short time. The use of the iron hydroxide precipitation step, in combination with the small resin cartridges $(2 \mathrm{~mL})$ and micro-columns (100 mg), reduces considerably the laboratory working time and the volumes of reagents. With this method, sample pretreatment and actinides extraction can be completed in two days for a batch of 6 soil samples $(20 \mathrm{~g})$.

In addition, the high selectivity of the TEVA and DGA resins leads to pure sources with high recoveries, even in samples with high iron content.

We observed that the use of two TEVA columns resulted in a very good separation of plutonium from uranium for $\alpha$-spectrometry; but still the separation was not completely satisfactory for the ICP-SMS measurement. Consequently, the formation rate of $\mathrm{UH}^{+}$was determined and its contribution to the ${ }^{239} \mathrm{Pu}$ spectral window was taken into account.

Acknowledgments We thank the Swiss National Fund for Scientific Research (grant 200021-115915) and the Swiss Federal Office of Public Health for financial support.

\section{References}

1. UNSCEAR: Ionizing radiation: sources and biological effects. In: Annex, E. (ed.) Exposures Resulting from Nuclear Explosions. Report to the General Assembly, pp. 211-248. United Nations Scientific Committee on the Effects of Atomic Radiation, New York (1982)

2. Goutelard, F., Morello, M., Calmet, D.: Alpha-spectrometry measurement of $\mathrm{Am}$ and $\mathrm{Cm}$ at trace levels in environmental samples using extraction chromatography. J. Alloys Compd. 271, 25-30 (1998)

3. Maxwell, S.L., Culligan, B.K.: Rapid column extraction method for actinides in soil. J. Radioanal. Nucl. Chem. 270, 699-704 (2006)

4. Mihai, S.A.: Sediment sample preparation for the determination of Pu and Am isotopes. J. Radioanal. Nucl. Chem. 266, 259-264 (2005)

5. Maxwell, S.L., Faison, D.M.: Rapid column extraction method for actinides and strontium in fish and other animal tissue samples. J. Radioanal. Nucl. Chem. 275, 605-612 (2008)

6. Becker, J.S., Zoriy, M., Halicz, L., Teplyakov, N., Muller, C., Segal, I., Pickhardt, C., Platzner, I.T.: Environmental monitoring of plutonium at ultratrace level in natural water (Sea of GalileeIsrael) by ICP-SFMS and MC-ICP-MS. J. Anal. At. Spectrom. 19, 1257-1261 (2004)

7. Donard, O.F.X., Bruneau, F., Moldovan, M., Garraud, H., Epov, V.N., Boust, D.: Multi-isotopic determination of plutonium (Pu239, $\mathrm{Pu}-240, \mathrm{Pu}-241$ and $\mathrm{Pu}-242$ ) in marine sediments using sector-field inductively coupled plasma mass spectrometry. Anal. Chim. Acta 587, 170-179 (2007)

8. Froidevaux, P., Haldimann, M.: Plutonium from above-ground nuclear tests in milk teeth: investigation of placental transfer in children born between 1951 and 1995 in Switzerland. Environ. Health Perspect. 116, 1731-1734 (2008)
9. Croudace, I., Warwick, P., Taylor, R.N., Dee, S.: Rapid procedure for plutonium and uranium determination in soils using a borate fusion followed by ion-exchange and extraction chromatography. Anal. Chim. Acta 371, 217-225 (1998)

10. Michel, H., Levent, D., Barci, V., Barci-Funel, G., Hurel, C.: Soil and sediment sample analysis for the sequential determination of natural and anthropogenic radionuclides. Talanta 74, 1527-1533 (2008)

11. Penrose, W.R., Polzer, W.L., Essington, E.H., Nelson, D.M., Orlandini, K.A.: Mobility of plutonium and americium through a shallow aquifer in a semiarid region. Environ. Sci. Technol. 24, 228-234 (1990)

12. Bossew, P., Lettner, H., Hubmer, A., Erlinger, C., Gastberger, A.: Activity ratios of Cs-137, Sr-90 and Pu239+240 in environmental samples. J. Environ. Radioact. 97, 5-19 (2007)

13. Hrnecek, E., Jakopic, R., Wallner, A., Steier, P.: Combined method for the determination of the isotopic vector of plutonium isotopes in environmental samples. J. Radioanal. Nucl. Chem. 276, 789-793 (2008)

14. Maxwell, S.L.: Rapid column extraction method for actinides and Sr-89/90 in water samples. J. Radioanal. Nucl. Chem. 267, 537543 (2006)

15. Moody, C.A., Glover, S.E., Stuit, D.B., Filby, R.H.: Pre-concentration and separation of thorium, uranium, plutonium and americium in human soft tissues by extraction chromatography. J. Radioanal. Nucl. Chem. 234, 183-187 (1998)

16. Pilvio, R., Bickel, M.: Actinoid separations by extraction chromatography. Appl. Radiat. Isot. 53, 273-277 (2000)

17. Lee, S.H., La Rosa, J., Gastaud, J., Povinec, P.P.: The development of sequential separation methods for the analysis of actinides in sediments and biological materials using anion-exchange resins and extraction chromatography. J. Radioanal. Nucl. Chem. 263, 419-425 (2005)

18. Toribio, M., Garcia, J.F., Rauret, G., Pilvio, R., Bickel, M.: Plutonium determination in mineral soils and sediments by a procedure involving microwave digestion and extraction chromatography. Anal. Chim. Acta 447, 179-189 (2001)

19. Horwitz, E.P., McAlister, D.R., Bond, A.H., Barrans, R.E.: Novel extraction of chromatographic resins based on tetraalkyldiglycolamides: characterization and potential applications. Solvent Extr. Ion Exch. 23, 319-344 (2005)

20. Maxwell, S.L., Culligan, B.K.: Rapid column extraction method for actinides in soil. J. Radioanal. Nucl. Chem. 270, 699-704 (2006)

21. Maxwell, S.L.: Rapid method for determination of plutonium, americium and curium in large soil samples. J. Radioanal. Nucl. Chem. 275, 395-402 (2008)

22. Bundesamt für Strahlenshutz (2008) Bestimmung von alphaStrahlern im Wasser. Fachbereich Strahlenschutz und Umwelt, B ed. (2008)

23. PROCORAD: Radiotoxicological intercomparison exercices. Transuranium actinides in fecal ash (2008)

24. PROCORAD: Radiotoxicological intercomparison exercices. Transuranium actinides in urines (2001)

25. Bajo, S., Eikenberg, J.: Electrodeposition of actinides for alphaspectrometry. J. Radioanal. Nucl. Chem. 242, 745-751 (1999)

26. Zheng, J., Yamada, M.: Investigating $\mathrm{Pu}$ and $\mathrm{U}$ isotopic compositions in sediments: a case study in Lake Obuchi, Rokkasho Village, Japan using sector-field ICP-MS and ICP-QMS. J. Environ. Monit. 7, 792-797 (2005)

27. Solovitch-Vella, N., Pourcelot, L., Chen, V.T., Froidevaux, P., Gauthier-Lafaye, F., Stille, P., Aubert, D.: Comparative migration behaviour of ${ }^{90} \mathrm{Sr},{ }^{239+240} \mathrm{Pu}$ and ${ }^{241} \mathrm{Am}$ in mineral and organic soils of France. Appl. Geochem. 22, 2526-2535 (2007) 